\title{
Exploring the Association between Job Satisfaction and Productivity: empirical evidence from India
}

\author{
Omar Abdu Saeed ${ }^{1,}{ }^{*}$, S.N.Waghule ${ }^{2}$ \\ ${ }^{1}$ Research Scholar, Department of commerce, Babasaheb Ambedkar Marath wada University, Aurangabad \\ 431001, India \\ ${ }^{2}$ Prefessor, Department of commerce, Babasaheb Ambedkar Marathwada University, Aurangabad 431001, \\ India
}

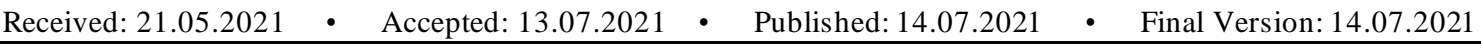

\begin{abstract}
The study aimed to study the impact of job satisfaction on employee's productivity. The study is based on primary data, which was collected from Poona College. The questionnaire was distributed to the employees in Poona College. According to H.R department, there are 300 employees in the college. They are taking place in every level and filed. In obtaining the sample size of the population, employees in Poona College were selected. The researcher further selected 15\% of employees, it was counted in the formula of $(300 * 15 / 100=45)$.

Results revealed that satisfied employees have positive attitudes about their jobs. Satisfied workers are tend to work on time, loyalty and commitment to the job, tend to improve knowledge, willing to accept more responsibility, with a reduction of absenteeism. The positive attitudes will increase the quality and quantity of employees' performance. Therefore, such a situation is good for an organization but some organizations do not concern about satisfaction of employees. Hence, if organizations can be more concerned about the job satisfaction of employees' better productivity can be expected, as the relationship between satisfaction and productivity is positive and significant. This aspect should be given more consideration by the managers in order to improve productivity.
\end{abstract}

Keywords: Job Satisfaction, Productivity, Loyalty, Commitment

\section{Introduction}

The concept of job satisfaction has been explained in different ways via various scholars and experts. In Greenberg and Baron's words (2008), job satisfaction was exposed as a feeling that can produce a positive or negative effect toward one's roles and responsibilities at work and added that it is important to understand the concept of job satisfaction as there is no single way to satisfy all workers in the workplace. They realized that a positive feeling toward a person's job.

Employee satisfaction is of utmost importance for employees to remain happy and also deliver their level best. Satisfied employees are the ones who are extremely loyal towards their organization and stick to it even in the worst scenario. They do not work out of any compulsion but because they dream of taking their organization to a better level. Employees need to be passionate towards their work and passion comes only when employees are satisfied with their job and organization on the whole. Employee satisfaction leads to a positive ambience at the workplace. People seldom crib or complain and concentrate more on their work.

The first benefit of employee satisfaction is that individuals hardly think of leaving their current jobs. Employee satisfaction in a way is essential for employee retention. Organizations need to retain 
deserving and talented employees for long term growth and guaranteed success. if people just leave you after being trained, trust me, your organization would be in a big mess. Agreed you can hire new individuals but no one can deny the importance of experienced professionals. It is essential for organizations to have experienced people around who can guide freshers or individuals who have just joined. Employee attrition is one of the major problems faced by organizations. I don't think an individual who is treated well at the workplace, has ample opportunities to grow, is appreciated by his superiors, gets his salary on time ever thinks of changing his job. Retaining talented employees definitely gives your organization an edge over your competitors as they contribute more effectively. Moreover, no new individual likes to join an organization which has a high employee attrition rate. Employees who are not satisfied with their jobs often badmouth their organization and also warn friends and acquaintances to join the same.

Employee satisfaction is essential to ensure higher revenues for the organization. No number of trainings or motivation would help, unless and until individuals develop a feeling of attachment and loyalty towards their organization. Employees waste half of their time fighting with their counter parts or sorting out issues with them. Trust me employees who are satisfied with their jobs seldom have the time to indulge in nasty office politics. They tend to ignore things and do not even have the time to crib or fight with others. Satisfied employees are the happy employees who willingly help their fellow workers and cooperate with the organization even during emergency situations. Such employees do not think of leaving their jobs during crisis but work hard together as a single unit to overcome challenges and come out of the situation as soon as possible. For them, their organization comes first, everything else later. They do not come to office just for money but because they really feel for the organization and believe in its goals and objectives. Satisfied employees also spread positive word of mouth and always stand by each other. Instead of wasting their time in gossiping and loitering around they believe in doing productive work eventually benefitting the organization. They take pride in representing their respective organizations and work hard to ensure higher revenues for the organization. Satisfied employees tend to adjust more and handle pressure with ease as compared to frustrated ones. Employees who are not satisfied with their jobs would find a problem in every small thing and be too rigid. They find it extremely difficult to compromise or cope up with the changing times. On the other hand, employees who are happy with their jobs willing participate in training programs and are eager to learn new technologies, softwares which would eventually help them in their professional career. Satisfied employees accept challenges with a big smile and deliver even in the worst of circumstances.

In general, employee satisfaction is one of the most important health and wellness indicators for the organization and its effectiveness on the assumption that a department where staff are not satisfied will have little success compared to satisfied staff, noting that the staff member is more willing to continue to function and achieve organizational objectives He is also more active and enthusiastic at work and the most important thing that distinguishes the importance of the study of job satisfaction is that it deals with the feelings of man about the work he does and the environment surrounding him.

One of the most important roles of Human Resource is to ensure that all employees are satisfied with their jobs hence, the satisfaction of employees will reflect to the productivity. However, the employees who are not satisfied their productivity will be less effective. Therefore, Human Resource should analyze and measure job satisfaction. In this study the problem arises when there is a need for measuring the job satisfaction in Poona College. The current study is giving an attempt to detect the extent of job satisfaction among employees in Poona Collage. 

India

\section{Literature review}

According to Singh and Dr. Mini Jain, 1 the productivity increases when the workers reach the happiness level. The authors have revealed that the job satisfaction to employee is a strength to act the constraints that might be occurred when the need arises for productivity in organizations. the right environment should be created effectively to maintain employee job satisfaction as well as improving the performance of workers.

Considering AZIRI (2011), Job satisfaction represents one of the most complex areas facing today's managers when it comes to managing their employees. Although thousands of papers and research have been conducted on job satisfaction all over the world, in the Republic of Macedonia this is one of the least studied research fields. Many studies have demonstrated an unusually large impact on the job satisfaction on the motivation of workers, while the level of motivation has an impact on productivity, and hence also on performance of business organizations. There is a considerable impact of the employees' perceptions for the nature of their work and the level of overall job satisfaction. Financial compensation has a great impact on the overall job satisfaction of employee.

According to Daneshfard and Ekvaniyan, (2012), educational institutions are professional service organizations and contribute services through their organization's members without exception. The relationship between employee job satisfaction and employee organizational commitment is existing and significant. Organ (1977) revealed that, job satisfaction will affect workers performance positively or negatively.

Resheske (2001) studied job satisfaction among full time faculty of the College of Human Development at Wisconsin University. Thirty-six full time faculty members were included in the study. The results indicated that overall, the faculty of the College of Human Development at UW-Stout was satisfied with their current employment and that group cohesion does play a role in overall job satisfaction. The study also determined that job autonomy, working with the students and fellow colleagues and supervisors were the top three best reasons for working here. It was also concluded that pay, having more time and assistance with meeting deadlines and having equal workloads between colleagues were the three top priorities for improving the work environment.

Sanjay Kumar in his study found that female university teachers are more satisfied with their job than the male teachers are. One thing common in male and female is that both are satisfied with their income per Annum and more than $75 \%$ of the respondents opined that handsome salary is job satisfaction. The majority of the respondents also sketches dignity and social status, job Security, job matching with qualifications, physical environment and to work in a desired Profession is job satisfaction. It is concluded that job satisfaction is the extent to which one feels good about the job. It is a pleasurable state resulting from the appraisal of one's job experience. The level of job Satisfaction may not be homogeneous. It may differ from person to person, place to place, job to Job, and institution to institution. In general, salaries, physical environment, job security, desired Profession, job matching with Academic qualifications, vacations and fringe benefits etc. affect the job satisfaction among the

Rinehart and Short (1993) indicated that teachers' job satisfaction is related to work environment, work involvement, morale, motivation to work, and school structure. Chen (2008) Job satisfaction is the individual degrees of a positive affective orientation, negative affective oriented are not satisfied with a positive affective work orientation. According to Po-Yao Chuang(2014), The relationship between employee job satisfaction and employee organizational commitment is direct and significant. Ahmed, Usman, and Rana(2011) mentioned that, job satisfaction also mediates (intervenes) the relationship between facets of job and citizenship behavior. Therefore, increasing the job satisfaction of the organizational members is the only way to really enhance the service quality of the educational 
institutions. foreign researchers confirmed that personal job satisfaction of the organization members has played an important role in promoting the entire performance.

Adeniji (2011) investigated the organizational climate and job satisfaction among Academic Staff in Some Selected Private Universities in Southwest Nigeria. The study was based on the responses received from 293 respondents of five private Universities in the South-West Zone of Nigeria. The results indicated a positive relationship between organizational climate and job satisfaction.

The study of Sabarinathan and Kumar resulted that the investigation depicts terrible picture of overall job satisfaction among college faculty. The faculty has shown satisfaction with the job motivator and hygiene factors of satisfaction. The response of the male and female faculty was more or less similar for the professional progress, relationship. A considerable number of female faculty members has remained undecided regarding various factors of job satisfaction and understandably so that in the society the female faculty does not always show their true opinion about the level of job satisfaction. The male faculty was more concerned about the professional development.

Maslow (1970) raised five Need's Hierarchy in self-fulfillment; esteem, love, belongingness, safety, and physiological needs; while, Alderfer (1972) maintained those needs between levels which are not mutually exclusive but could be conductible simultaneously and separated the Maslow's theory into existence.

McClelland (1976) studied the job satisfaction behavior in Indiana University. The study revealed that a number of studies have indicated that satisfaction perceptions vary on the basis of age, sex in the organization. Education, type, job level and like. If job satisfaction was clarified and satisfaction denotes some internal state, the reliability of satisfaction becomes a crucial issue.

Cardona (1996) in a survey of members of the Association for Investment Management and Research found that $81 \%$ of the managers were satisfied or very satisfied with their job. Most managers named professional achievement, personal or professional growth, the work itself and their degree of responsibility more important than compensation as the factors that create positive feelings about their job. Factors like company policies, administration, relationships with supervisors, compensation and the negative impact of work on their personal lives were viewed as those which create negative feelings about the job.

Rajgopal (1965) in his study pointed the relationship between satisfaction and productivity of textile mills workers belonging to high and low productive mills. Six mills, three high and three low (Productivity was indexed in terms of operative hours per unit of Production for the past three years) were chosen for the study. 75 workers each from high Productive and low Productive mills were chosen for the study. They were asked to indicate their degree of satisfaction/dissatisfaction on a 5-point scale ranging from extreme satisfaction to extreme dissatisfaction on thirty items representing seven aspects of work salary, job, management, working condition, welfare facilities, coworkers, and union management relations. The results highlighted that high productive mill workers were significantly more satisfied with five of the seven aspect excluding job and coworkers.

\section{Research methodology}

Data can be collected from two sources, primary and secondary sources. In this research the primary data was collected from original sources by questionnaires. The primary data was collected from Poona College. Employees were randomly selected to fill the questionnaire. The questionnaire was employed to collect the required data and it was sent to participants that were randomly selected. The questionnaire was distributed to the employees in Poona College. According to H.R department there are 300 employees in the college. They are taking place in every level and filed. In obtaining the sample size of the population, employees in Poona College were selected. The researcher further selected $15 \%$ of employees, it was counted in the formula of $(300 * 15 / 100=45)$. 
Table 1. Shows the sample size that has been formulated after survey with complete universe.

\begin{tabular}{lccccc}
\hline Population & Selected & Distributed & Received & Invalid & Valid \\
\hline 300 & 45 & 45 & 40 & 4 & 36 \\
\hline
\end{tabular}

Respondents were asked to comment on the job satisfaction and productivity with five options ( $1=$ strongly disagree, $2=$ Disagree, $3=$ Neutral, $4=$ Agree, $5=$ strongly agree). They were further provided with the following statements:

1. Management provides effective leadership for achieving job satisfaction to employees

2. Management allows employees for more creativity and personalization

3. Managers directly impact employees 'day-to-day' job satisfaction

4. Reaching the job satisfaction level to employees helps in increasing the productivity

5. Management provides rewards to employees for better productivity

6. Working-time is managed properly to achieve the productivity.

The reliability was tested by Cronbanch's Alpha Method. Cronbach's alpha is the most common measure of internal consistency ("reliability")

Table 2. Reliability of the questionnaire by Cronbanch's Alpha Method

\begin{tabular}{lcc}
\hline Dimension & No of Items & Reliability \\
\hline Job Satisfaction and Productivity & 6 & .645 \\
\hline
\end{tabular}

From table 2, it is clear that, the rates of internal consistency is above 0.6 counted by Cronbach's alpha We can see Cronbach's alpha is 0.645 of all scales questions, which indicates a high level of internal consistency.

\section{Data analysis and interpretation}

There are different important measures that can be used in presenting and analyzing data. These measures give a clear idea about the distribution of observations in the set of data. All those theses measures can be called descriptive statistics. In this section, the collected data has been presented and analyzed using SPSS.

Table 3. Frequency Statistics for leadership for Job Satisfaction

\section{1: Management provides effective leadership for achieving job satisfaction to employees}

\begin{tabular}{llllll}
\hline & Frequency & Percent & Valid Percent & $\begin{array}{l}\text { Cumulative } \\
\text { Percent }\end{array}$ \\
\hline Valid & Strongly Disagree & 2 & & & 5.6 \\
& Disagree & 2 & 5.6 & 5.6 & 11.1 \\
& Neutral & 12 & 33.3 & 3.6 & 44.4 \\
& Agree & 14 & 38.9 & 38.9 & 83.3 \\
& Strongly Agree & 6 & 16.7 & 16.7 & 100.0 \\
& Total & 36 & 100.0 & 100.0 & \\
\hline
\end{tabular}




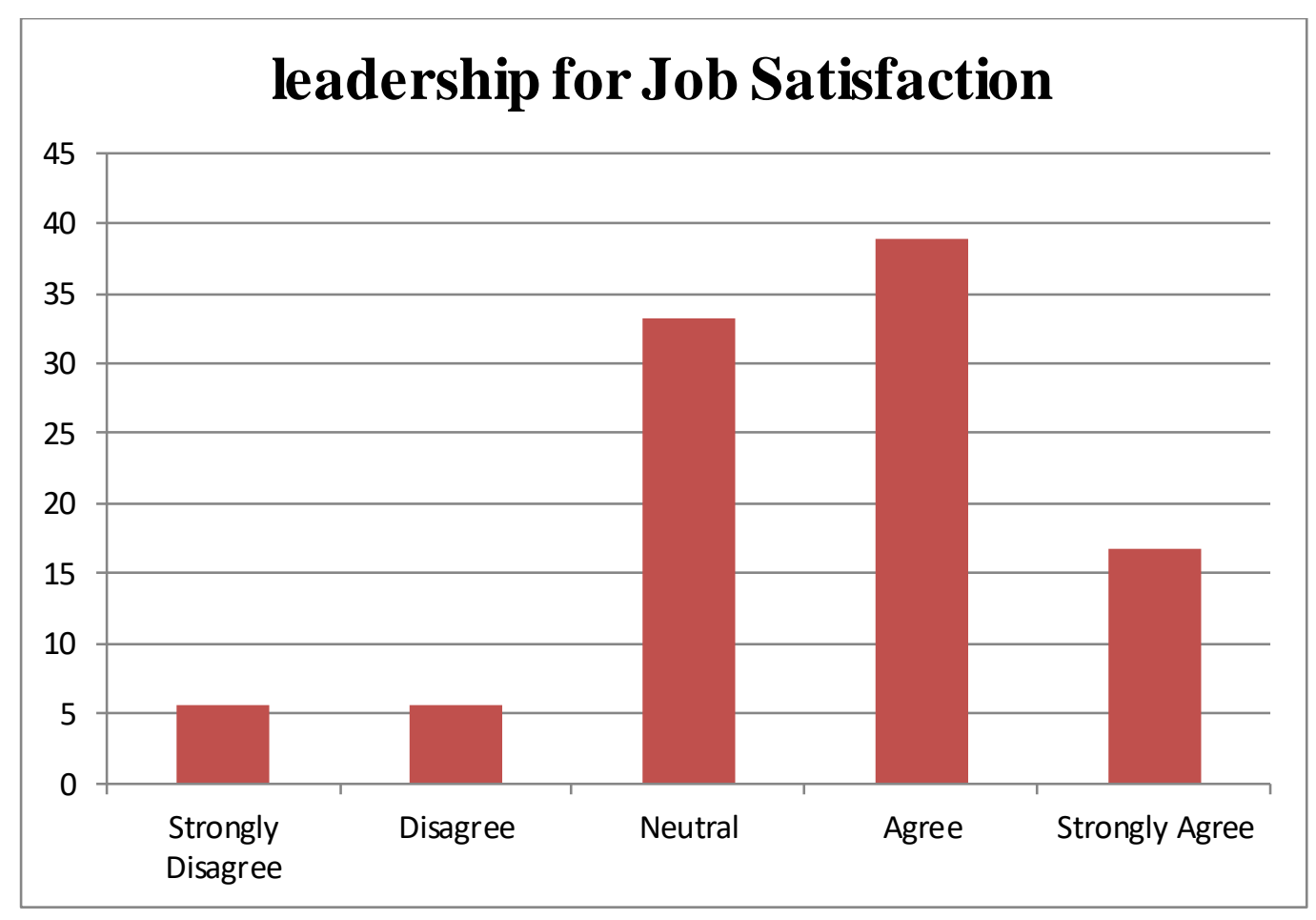

Figure 1. Leadership for Job Satisfaction

Table 3 and figure 1 show that $38.9 \%$ of the respondents agreed that management provides effective leadership for achieving job satisfaction to employees while $16.7 \%$ had similar opinion. On the other hand $33.3 \%$ of the respondents stated at neutral level in concern providing effective leadership for achieving job satisfaction to employees.

\section{2: Management allows employees for more creativity and personalization}

Table 4. Frequency Statistics for Creativity and Personalization

\begin{tabular}{llllll}
\hline & & $\begin{array}{l}\text { Frequenc } \\
\mathrm{y}\end{array}$ & Percent & Valid Percent & $\begin{array}{l}\text { Cumulative } \\
\text { Percent }\end{array}$ \\
\hline Valid & Disagree & 4 & 11.1 & 11.1 & 11.1 \\
& Neutral & 2 & 5.6 & 5.6 & 16.7 \\
& Agree & 18 & 50.0 & 50.0 & 66.7 \\
& Strongly Agree & 12 & 33.3 & 33.3 & 100.0 \\
& Total & 36 & 100.0 & 100.0 & \\
\hline
\end{tabular}




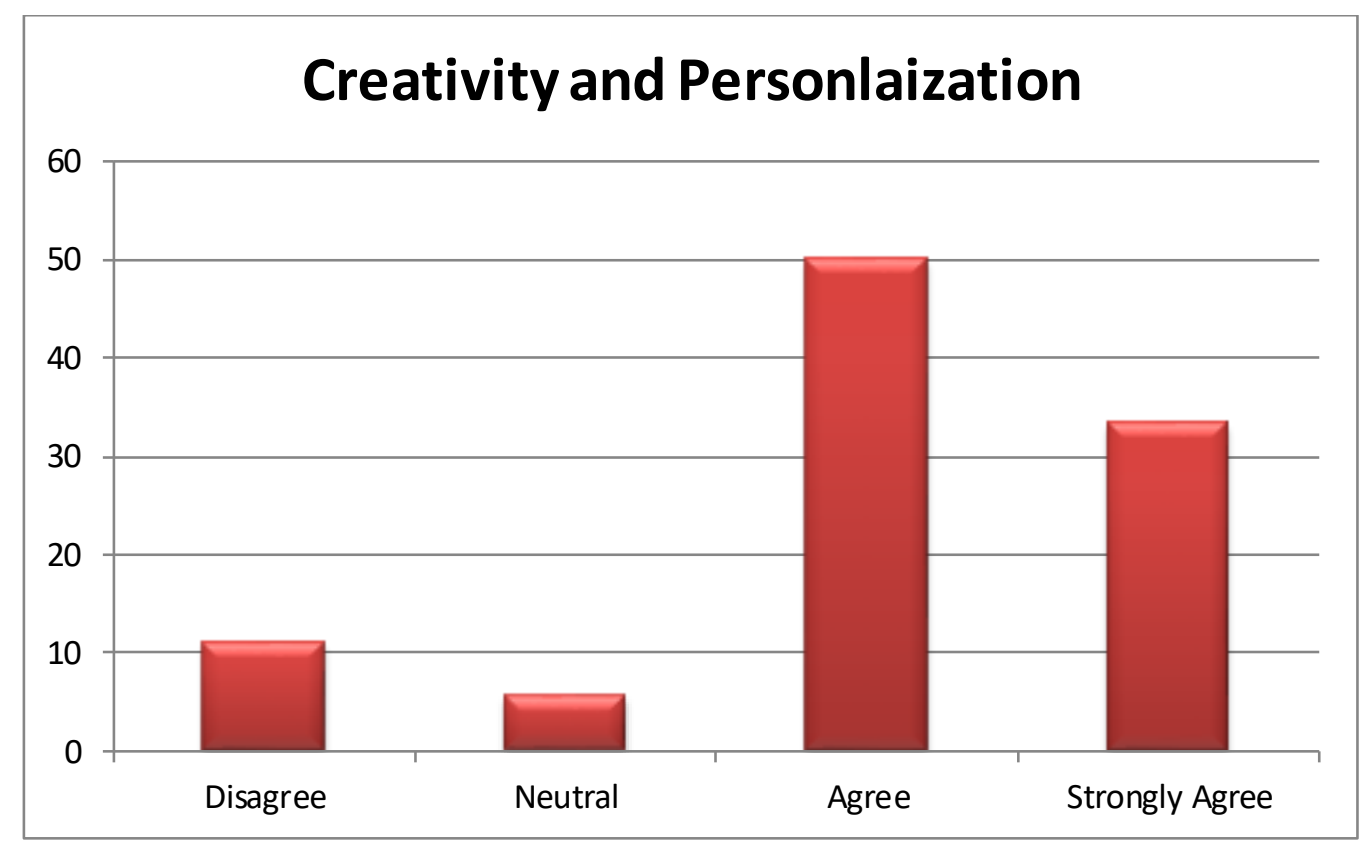

Figure 2. Creativity and Personalization

Table 4 and figure 2 show that $50.0 \%$ of the respondents agreed that management allows employees for more creativity and personalization while $33.3 \%$ had similar opinion, on the other hand $5.6 \%$ of the respondents were stated at neutral level regarding management allows employees for more creativity and personalization.

3: Managers directly impact employees 'day-to-day' job satisfaction

Table 5. Frequency Statistics for 'day-to-day' Job Satisfaction

\begin{tabular}{llllll}
\hline & Frequency & Percent & Valid Percent & $\begin{array}{l}\text { Cumulative } \\
\text { Percent }\end{array}$ \\
\hline Valid & Neutral & 12 & 33.3 & 33.3 & 33.3 \\
& Agree & 18 & 50.0 & 50.0 & 83.3 \\
& Strongly Agree & 6 & 16.7 & 16.7 & 100.0 \\
& Total & 36 & 100.0 & 100.0 & \\
\cline { 2 - 5 }
\end{tabular}

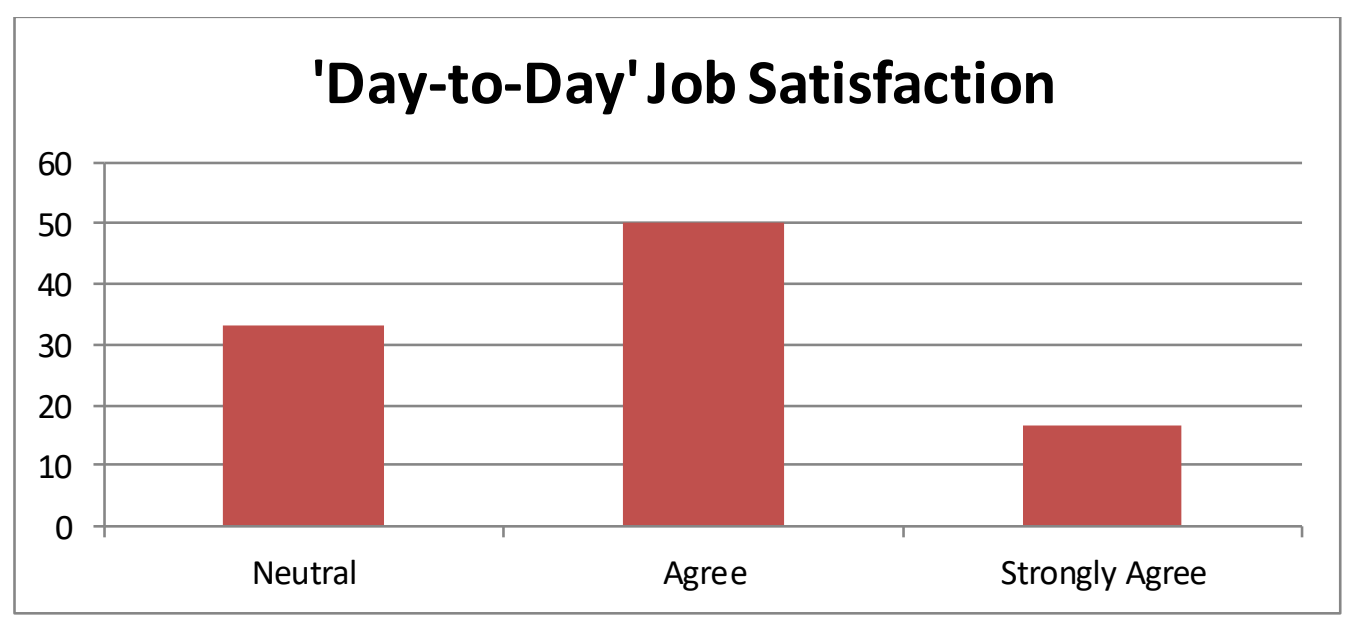

Figure 3. Day to Day Job Satisfaction 
Table 5 and figure 3 show that $50.0 \%$ of the respondents agreed that managers directly impact employees 'day-to-day' job satisfaction while $16.7 \%$ had similar opinion, on the other hand $33.3 \%$ of the respondents were neutral regarding managers directly impact employees 'day-to-day' job satisfaction.

\section{4: Reaching the job satisfaction level to employees helps in increasing the productivity}

Table 6. Frequency Statistics for Productivity

\begin{tabular}{llllll}
\hline & Frequency & Percent & Valid Percent & $\begin{array}{l}\text { Cumulative } \\
\text { Percent }\end{array}$ \\
\hline Valid & Disagree & 2 & 5.6 & 5.6 & 11.1 \\
& Neutral & 12 & 33.3 & 33.3 & 44.4 \\
& Agree & 14 & 38.9 & 38.9 & 83.3 \\
& Strongly Agree & 6 & 16.7 & 16.7 & 100.0 \\
& Total & 36 & 100.0 & 100.0 & \\
& & & & \\
\hline
\end{tabular}

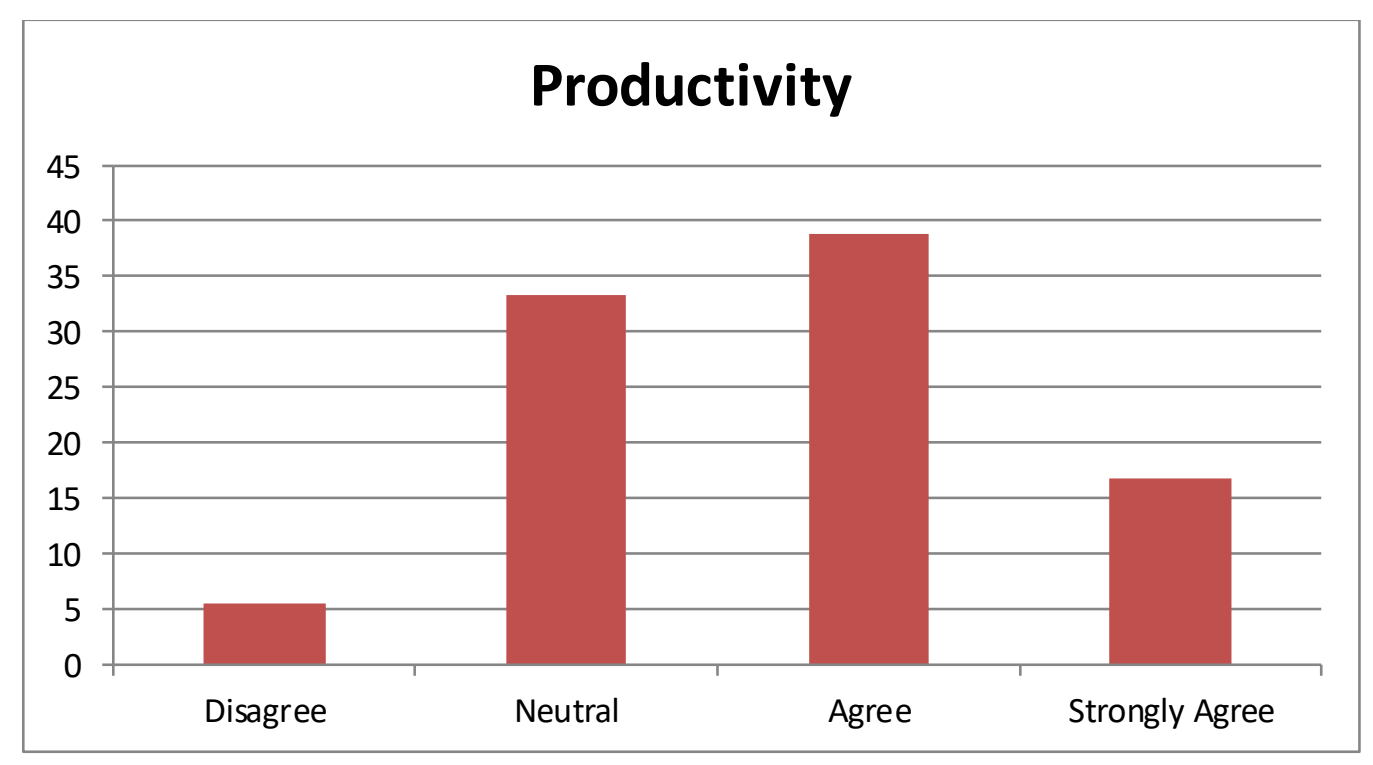

Figure 4. Productivity

Table 6 and figure 4 show that $38.9 \%$ of the respondents agreed that reaching the job satisfaction level to employees helps in increasing the productivity while $16.7 \%$ had similar opinion, However $33.3 \%$ of the respondents were neutral regarding reaching the job satisfaction level to employees helps in increasing the productivity. 
68 Saeed and Waghule, Exploring the Association between Job Satisfaction and Productivity: empirical evidence from India

5: Management provides rewards to employees for better productivity

Table 7. Frequency Statistics for Rewards

\begin{tabular}{llllll}
\hline & Frequency & Percent & Valid Percent & $\begin{array}{l}\text { Cumulative } \\
\text { Percent }\end{array}$ \\
\hline Valid & Disagree & 14 & 38.9 & 38.9 & 38.9 \\
& Neutral & 6 & 16.7 & 16.7 & 55.6 \\
& Agree & 10 & 27.8 & 27.8 & 83.3 \\
& Strongly Agree & 6 & 16.7 & 16.7 & 100.0 \\
& Total & 36 & 100.0 & 100.0 & \\
\hline
\end{tabular}

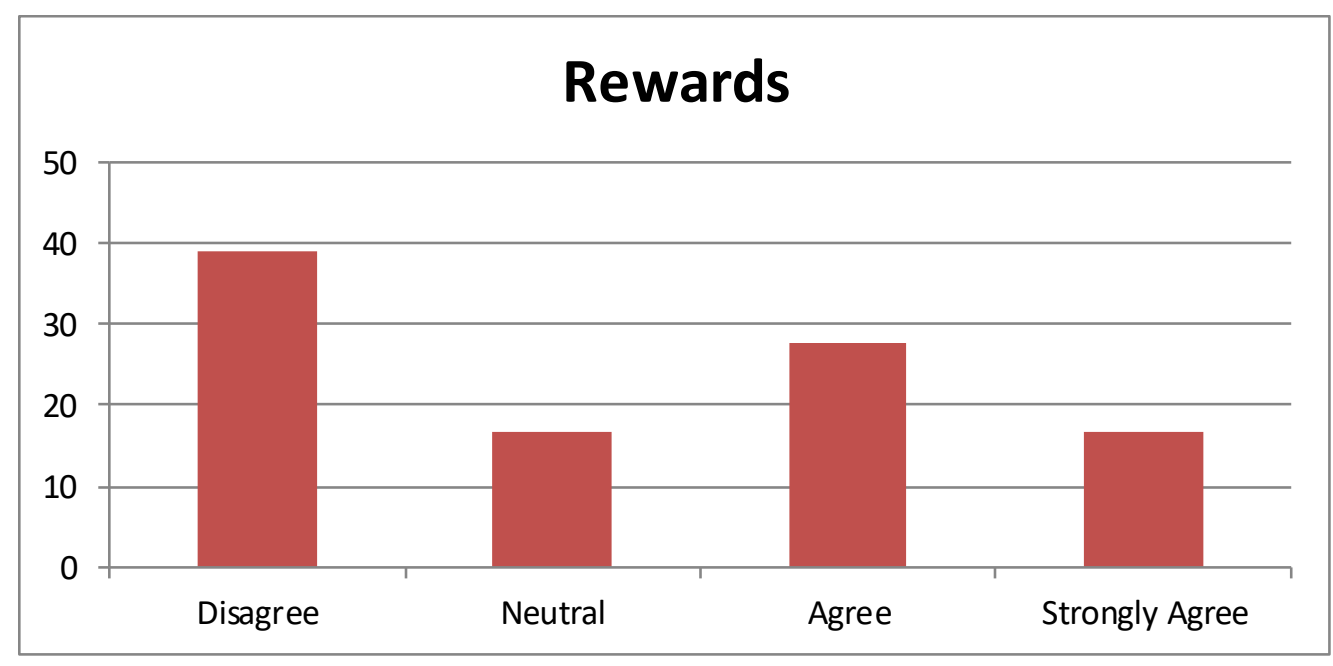

Figure 5. Rewards

Table 7 and figure 5 show that $38.9 \%$ of the respondents disagreed that management provides rewards to employees for better productivity while $16.7 \%$ had similar opinion, However $27.8 \%$ of the respondents were agreed regarding reaching management provides rewards to employees for better productivity.

6: Working-time is managed properly to achieve the productivity

Table 8. Frequency Statistics for Achieve the Productivity

\begin{tabular}{llllll}
\hline & & Frequency & Percent & Valid Percent & $\begin{array}{l}\text { Cumulative } \\
\text { Percent }\end{array}$ \\
\hline Valid & Strongly disagree & 8 & & & 22.2 \\
& Neutral & 2 & 5.6 & 5.6 & 27.8 \\
& Agree & 22 & 61.1 & 61.1 & 88.9 \\
& Strongly Agree & 4 & 11.1 & 11.1 & 100.0 \\
& Total & 36 & 100.0 & 100.0 & \\
\hline
\end{tabular}




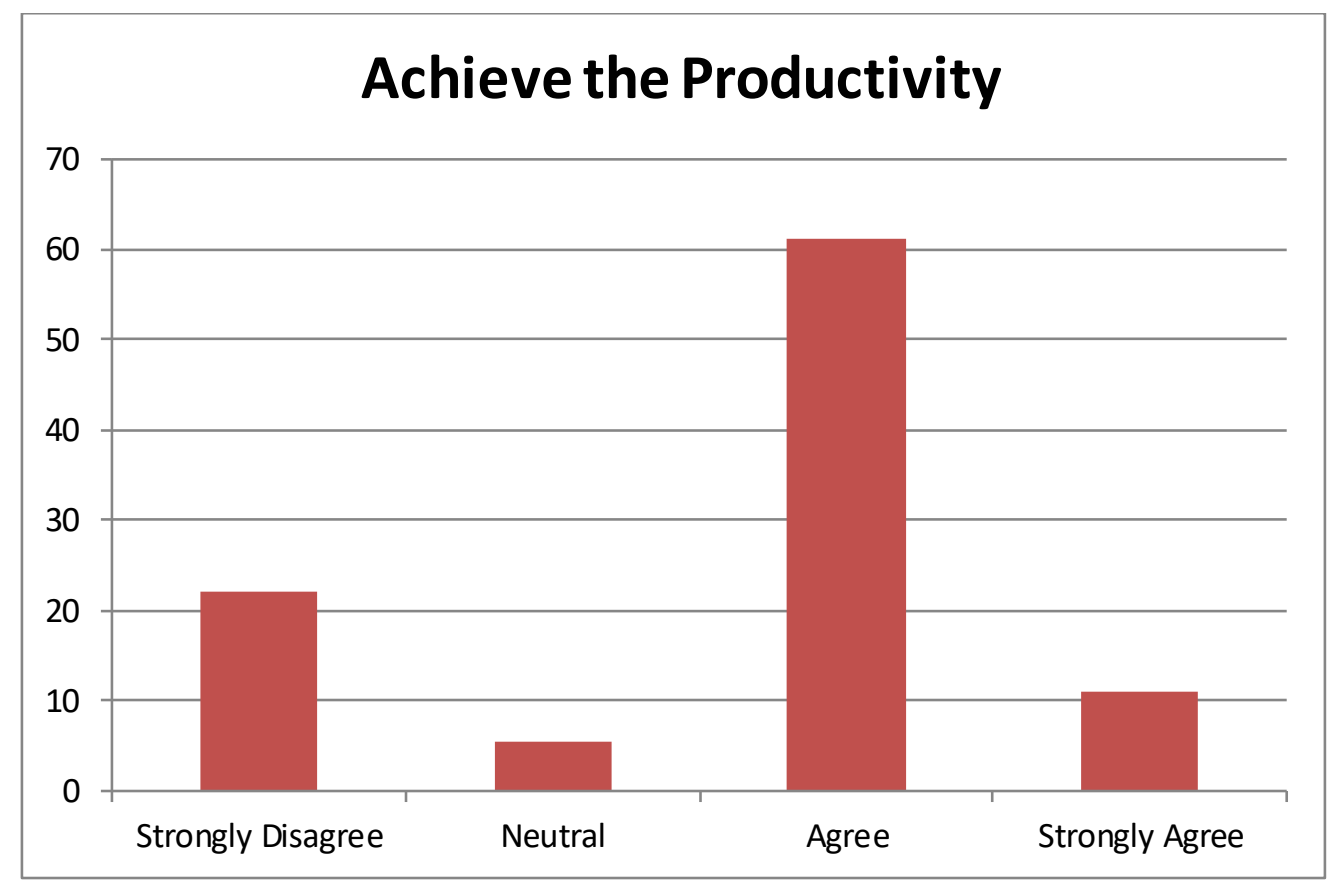

Figure 6. Achieve the Productivity

Table 8 and figure 6 show that $61.1 \%$ of the respondents agreed that working-time is managed properly to achieve the productivity, However $22.2 \%$ of the respondents were strongly disagreed regarding working-time is managed properly to achieve the productivity.

\section{Regression Test:}

\begin{tabular}{llllll}
\hline \multicolumn{6}{c}{ Model Summary $^{\mathbf{b}}$} \\
\hline \multirow{2}{*}{ Model } & $\mathrm{R}$ & R Square & $\begin{array}{l}\text { Adjusted } \\
\text { R Square }\end{array}$ & $\begin{array}{l}\text { Std. Error of } \\
\text { the Estimate }\end{array}$ & $\begin{array}{l}\text { Durbin- } \\
\text { Watson }\end{array}$ \\
\hline 1 & $.449 \mathrm{a}$ & .201 & .178 & .80755 & 1.603 \\
\hline
\end{tabular}

a. Predictors: (Constant), SATIS

b. Dependent Variable: PRODUCTIVITY

Results in table reveal that job satisfaction explains about $20 \%$ from the changes in the productivity and the rest is explained by other factors that are not included in this study.

\begin{tabular}{|l|l|c|c|c|c|c|}
\hline \multicolumn{7}{|c|}{ ANOVA $^{\text {a }}$} \\
\hline \multicolumn{2}{|c|}{ Model } & $\begin{array}{c}\text { Sum of } \\
\text { Squares }\end{array}$ & df & $\begin{array}{c}\text { Mean } \\
\text { Square }\end{array}$ & F & Sig. \\
\hline \multirow{4}{*}{1} & Regression & 5.593 & 1 & 5.593 & 8.576 & $.006^{\text {b }}$ \\
& Residual & 22.173 & 34 & .652 & & \\
& Total & 27.765 & 35 & & & \\
\hline
\end{tabular}

a. Dependent Variable: PRODUCTIVITY

b. Predictors: (Constant), SATIS 
The table shows that the model is fit in predicting the outcomes as the pv of the model is less than 0.05 .

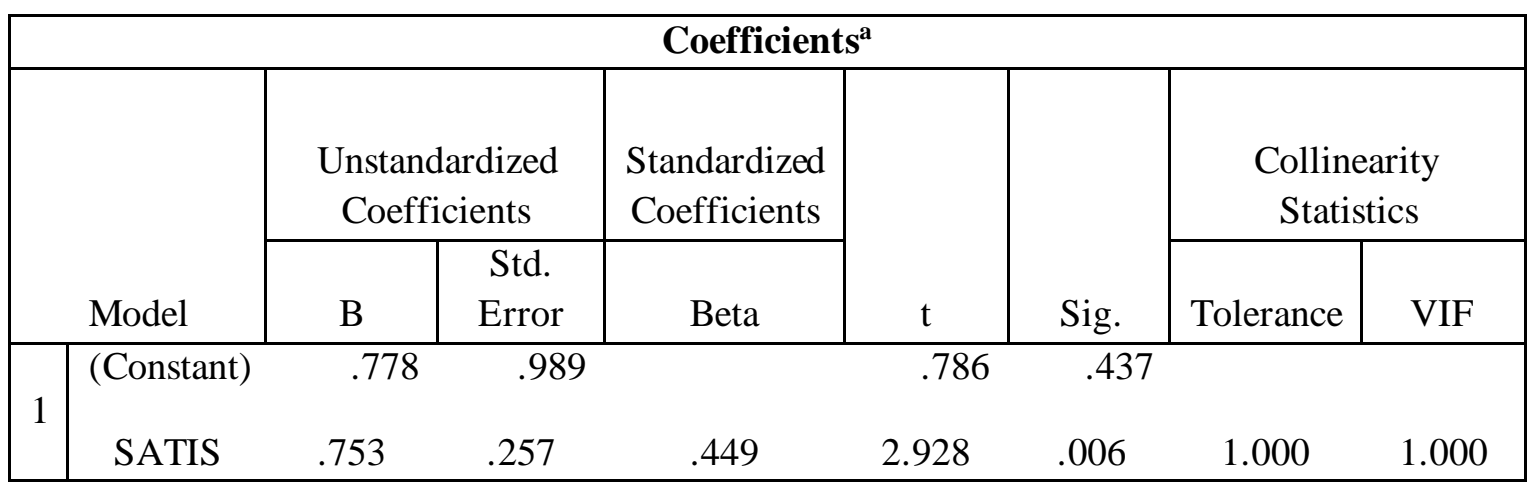

a. Dependent Variable: PRODUCTIVITY

The table shows that job satisfaction has a positive and significant impact on productivity of college employees. This means that when job satisfaction increases, the productivity of college employees' increases.

\section{Conclusion}

The study aimed to study the impact of job satisfaction on employee's productivity. The study is based on primary data, which was collected from Poona College.

The questionnaire was distributed to the employees in Poona College. According to H.R department, there are 300 employees in the college. They are taking place in every level and filed. In obtaining the sample size of the population, employees in Poona College were selected. The researcher further selected $15 \%$ of employees, it was counted in the formula of $(300 * 15 / 100=45)$.

Results revealed that satisfied employees have positive attitudes about their jobs. job satisfaction has a positive and significant impact on productivity of college employees. This means that when job satisfaction increases, the productivity of college employees' increases. Satisfied workers are tend to work on time, loyalty and commitment to the job, tend to improve knowledge, willing to accept more responsibility, with a reduction of absenteeism. The positive attitudes will increase the quality and quantity of employees' performance. Therefore, such a situation is good for an organization but some organizations do not concern about satisfaction of employees. hence, if organizations can be more concerned about the job satisfaction of employees better productivity can be expected, as the relationship between satisfaction and productivity is positive and significant. This aspect should be given more consideration by the managers in order to improve productivity.

The study has the following limitations:

1) The reliability of the study depends on the authenticity of information which will be provided by the respondents in Poona College.

2) Methodology, Data collection and analyses may have their own Limitation.

The population is limited to the stuff and faculties of Poona College.

\section{References}

[1] AMRIK SUDAN and NAVEEN KUMAR.(2003), Management Process and Organizational Behaviour, Published by Anmol publications, New Delhi-1 10002.

[2] ASHOK PUROHIT and AMBIKA GOYAL (2012), Organizational Beha viour, Published by Sonali publications, New Delhi-110002. 
[3] Brikend AZIRI (2011), JOB SATISFACTION: A LITERATURE REVIEW, MANAGEMENT RESEARCH AND PRACTICE VOL. 3 ISSUE 4 PP: 77-86.

[4] Dr. Jhajharia and Gupta(2015), A Study of Employee Satisfaction and Its Impact on Employee Retention in Retail Sector, IOSR Journal of Business and Management (IOSR-JBM) e-ISSN: 2278-487X, p-ISSN: 2319-7668. Volume 17, Issue 7.Ver. I (July 2015), PP 01-07

[5] http://www.akipoonacollege.ac.in/components/

[6] http://www.managementstudyguide.com/importance-of-employee-satisfaction.htm

[7] http://wwwbiz.meijou.ac.jp/SEBM/ronso/no9_1/08_PUSHPAKUMARI.pdf

[8] https://www.boundless.com/management/textbooks/boundless-management-textbook/organizationalbehavior-5/drivers-of-behavior-44/defining-job-satisfaction-231-7247/

[9] https://www.ukessays.com/essays/psychology/the-concept-and-definition-of-job-satisfaction-psychologyessay.php

[10] Konstantinos Fassoulis, Nikolaos Alexopoulos, The workplace as a factor of job satisfaction and productivity, A case study of administrative personnel at the University of Athens, Journal of Facilities Management. 7 Sep- 2015.

[11] L M PRASAD(2007),Principles and Practice of Management, seventh Edition 2007, Published by Sultan Chand \& Sons, New Delhi-110002.

[12] Ms. Misha, Ms. Ankita ,Prof.(Dr.) Ma dan(2016), A COMPREHENSIVE LITERATURE REVIEW ON EMPLOYEE JOB SATISFACTION, International Journal of Science Technology and Management, Vol 5 , Issu 1 , January.

[13] Po-Yao Chuang(2014), Job Sa tisfaction of University Staff, The Journal of Human Resource and Adult Learning, Vol. 10, Num. 1, June issue.

[14] Sabarinathan and Kumar, A Study On Job Satisfaction Among The College Fa culty In Erode, IOSR Joumal of Business and Management (IOSR-JBM) e-ISSN : 2278-487X, p-ISSN : 2319-7668, PP 16-18.

[15] Sanjay Kumar, Job Satisfaction among University Teachers: A Case of Haridwar (Uttrakhand), June 2013 Vol-I Issue - 2

[16] Singh and Dr. Mini Ja in(2013), A STUDY OF EMPLOYEES' JOB SATISFACTION ANDITS IMPACT ON THEIR PERFORMANCE Journal of Indian Research (ISSN: 2321-4155) Vol.1, No.4, OctoberDecember, 2013, 105- 111. 